\title{
Direct Gene Transfer into Cardiac Myocytes in Vivo
}

\author{
Eliav Barr,* Hua Lin, $†$ Michael S. Parmacek,* and Jeffrey M. Leiden* \\ ${ }^{*}$ Department of Medicine, University of Chicago, Chicago, Illinois 60637; and $\dagger$ Department of Surgery, University \\ of Michigan Medical Center, Ann Arbor, Michigan 48109
}

\begin{abstract}
Recent studies have demonstrated that cardiac and skeletal myocytes share the ability to take up and stably express plasmid DNA injected directly into myocardium or skeletal muscle in vivo. Although this is a relatively inefficient process, with less than $1 \%$ of the myocytes expressing the injected recombinant DNA, expression in these cells is stable for periods of at least 6 months. The majority of the injected DNA is maintained in myocytes as an episome and apparently does not undergo DNA replication. The direct DNA injection approach has been used to map cardiac-specific transcriptional regulatory elements in cellular promoter/enhancers. Expression of recombinant proteins in the heart following direct DNA injection also holds promise for the treatment of a variety of acquired and inherited cardiovascular diseases. (c) 1992 Academic Press, Inc.
\end{abstract}

A comprehensive analysis of the molecular mechanisms regulating cardiac gene expression and development has been hindered significantly by our inability to grow and manipulate cardiac myocytes in vitro. Thus, for example, relatively little is currently understood about the transcriptional mechanisms regulating cardiac muscle development. Similarly, it has not been possible to develop therapeutic strategies for cardiovascular diseases based upon stably manipulating cardiac gene expression in vitro or in vivo. Recent studies have demonstrated that skeletal and cardiac myocytes share the unique ability to take up and stably express plasmid DNA following direct injection into skeletal or cardiac muscle in vivo (1-5). These findings have raised the possibility of using direct DNA injection both as a tool for studying transcriptional regulation in cardiac myocytes in vivo and as a method for programming the expression of therapeutic recombinant proteins in the heart. In this article, we provide a detailed description of the methods used for direct DNA injection into myocardium and discuss the uses of this technique for studying transcriptional regulation in cardiac muscle as well as for somatic gene therapy in the heart. We have demonstrated that direct DNA injection can be used to express a variety of reporter genes in rodent myocardial cells in vivo for periods of as long as 6 months. In addition, we have used direct DNA injections into rat myocardium to identify and characterize a novel cardiac-specific promoter/enhancer in the slow/ cardiac troponin $\mathrm{C}$ (cTnC) gene. We discuss the potential role of intracardiac DNA injection as an approach to somatic gene therapy in the heart.

\section{MATERIALS AND REAGENTS}

\section{Animals}

Sprague-Dawley rats, ages 4-6 weeks: Charles River.

\section{Solutions for DNA Preparation}

3 M sodium acetate, $\mathrm{pH} 5.2$.

$100 \%$ ethanol.

$70 \%$ ethanol in water.

$10 \mathrm{mM} \mathrm{NaH}_{2} \mathrm{PO}_{4}, \mathrm{pH} 7.4$, in $0.88 \%$ sodium chloride (filter sterilized).

$\mathrm{CsCl}$ : Optical grade, Ultrapure BRL.

Water-saturated 1-butanol. 
Dialysis tubing, $\frac{3}{4}$-in. diameter: BRL.

\section{Anesthetic Agents}

Avertin (2,2,2-tribromoethanol and tert-amyl alcohol), $5 \%$ vol/vol in Dulbecco's PBS (filter sterilized). Avertin should be prepared fresh on the day of surgery: Aldrich.

Ketamine: Aveco.

Pentobarbital: Anthony Products.

\section{Surgical Equipment}

Small-animal ventilator: Harvard Model 683.

Veterinary laryngoscope with small base and halogen lamp: Welch Allyn.

Miller blade size 0 (pediatric): Welch Allyn.

Angiocatheter or long percutaneous catheter, 18- or 20 -gauge size.

Animal clippers: Oster.

$70 \%$ ethanol.

Scalpel; coarse dissecting scissors; iris scissors, 4 in., curved; Castroviejo corneal scissors, $3.75 \mathrm{in}$. with blunt points; Hartmann mosquito forceps, 3.5 in., curved; Halsted mosquito forceps, 5 in., straight and curved; cross-action retractor, 4 in., with blunt prongs; MayoHegar needle holder, 5 in.; Autoclip wound clip applier with 9-mm wound clips, Roboz or Milltex.

30 -gauge $\times \frac{1}{2}$-in. needle.

21 gauge $\times 1$-in. needle.

1 -ml Tuberculin syringe.

20 -gauge angiocatheter.

4-O silk suture with conventional cutting (PC-5) needle.

4-O prolene suture with conventional cutting (PC5) needle.

4-O vicryl suture with conventional cutting (PC-5) needle.

Reagents for $\beta$-Galactosidase ( $\beta$-Gal), Chloramphenicol Acetyltransferase (CAT), and Luciferase Assays

$\beta$-Gal Assay

Glutaraldehyde, $1.25 \%$ (vol/vol) in Dulbecco's PBS: BRL. Ferro/ferricyanide solution: $0.1 \mathrm{M}$ potassium ferricyanide, $0.1 \mathrm{M}$ potassium ferrocyanide in distilled water. Store in the dark at room temperature.

X-Gal stock solution: $20 \mathrm{mg} / \mathrm{ml} \mathrm{X-Gal} \mathrm{(5-bromo-4-}$ chloro-3-indolyl- $\beta$-galactoside): $\mathrm{BRL}$ or BMB in $100 \%$ $N, N$-dimethyl formamide. Store in the dark at $-20^{\circ} \mathrm{C}$.

Staining solution: $50 \mathrm{mM}$ Tris- $\mathrm{HCl}(\mathrm{pH} 7.5)$, ferro/ ferricyanide solution ( $5 \%$ ), $15 \mathrm{mM} \mathrm{NaCl}, 1 \mathrm{mM} \mathrm{MgCl}_{2}$, $0.5 \mathrm{mg} / \mathrm{ml} \mathrm{X}$-Gal reagent.
Dulbecco's PBS, calcium and magnesium free.

\section{CAT Assay}

Protein colorimetric quantitation kit: Bio-Rad.

${ }^{14} \mathrm{C}$-labeled chloramphenicol (D-threo-[dichloroacetyl-1- ${ }^{14} \mathrm{C}$ ]chloramphenicol), $50-60 \mathrm{mCi} / \mathrm{mmol}$ : Amersham.

$2 \mathrm{M}$ Tris- $\mathrm{HCl}, \mathrm{pH} 7.4$.

$4 \mathrm{mM}$ acetyl-CoA: Pharmacia.

Ethyl acetate.

Thin-layer chromatography plates: Baker silica gel 1B-F.

X-ray film.

$95 \%$ chloroform $/ 5 \%$ methanol solution.

Ice-cold Dulbecco's PBS.

\section{Luciferase Assay}

Luciferin: Analytical luminescence.

Luciferase: Analytical luminescence.

$1 \mathrm{mM} \mathrm{D}$-luciferin in water. Store at $-20^{\circ} \mathrm{C}$ in the dark.

Luciferase enzyme stock solution: $2 \mathrm{mg} / \mathrm{ml}$ in $0.1 \mathrm{M}$ sodium phosphate, $\mathrm{pH} 7.8$. Store at $-20^{\circ} \mathrm{C}$ in the dark.

Luciferase buffer 1: $25 \mathrm{mM}$ glycylglycine, $\mathrm{pH} 7.8,15$ $\mathrm{mM} \mathrm{MgSO}_{4}$, $4 \mathrm{mM}$ EGTA, $1 \mathrm{mM}$ dithiothreitol, $1 \mathrm{mM}$ PMSF (phenylmethanesulfonyl fluoride).

Luciferase buffer 2: $0.27 \%$ Triton X-100, $25 \mathrm{mM}$ glycylglycine, $\mathrm{pH} 7.8,15 \mathrm{mM} \mathrm{MgSO}_{4}, 4 \mathrm{mM}$ EGTA, $1 \mathrm{mM}$ DTT, $15 \mathrm{mM} \mathrm{KH}_{2} \mathrm{PO}_{4}, 2 \mathrm{mM}$ ATP.

Luciferase buffer 3: $0.2 \mathrm{mM}$ luciferin, $25 \mathrm{mM}$ glycylglycine, $\mathrm{pH} 7.8,15 \mathrm{mM} \mathrm{MgSO}_{4}, 4 \mathrm{mM}$ EGTA, $2 \mathrm{mM}$ dithiothreitol.

PMSF: $100 \mathrm{mM}$ reconstituted in $100 \%$ ethanol. Store at $-20^{\circ} \mathrm{C}$.

\section{Equipment for $\beta$-Gal, CAT, and Luciferase Assays}

$\beta$-Gal Assay

$37^{\circ} \mathrm{C}$ incubator.

\section{CAT Assay}

Tissue homogenizer: Brinkmann.

Centrifuge: Beckman J-21.

$68^{\circ} \mathrm{C}$ water bath.

$37^{\circ} \mathrm{C}$ water bath.

Microcentrifuge: Eppendorf.

Speedy-Vac: Savant.

Thin-layer chromatography chamber.

Betascope 603: Betagen. 
Luciferase Assay

Luminometer: Pharmacia Bio-Orbit 1251.

\section{METHODS}

\section{Selection of Reporter Genes for Studies of Cardiac Transcriptional Regulation}

Several different reporter genes have been used for studies of transcriptional regulation following direct DNA injection into myocardium. These include $\beta$-galactosidase, chloramphenicol acetyltransferase, and firefly luciferase. These genes were chosen because they are not expressed in cardiac myocytes in vivo and because they can be easily assayed either in vivo or in vitro. Each gene offers unique advantages. $\beta$-Gal is a bacterial enzyme whose expression can be directly visualized in standard histological specimens using a commercially available chromogenic substrate that causes cells expressing the enzyme to stain blue (6). Thus, histochemical staining for $\beta$-Gal can be used to determine the number and type of cells expressing recombinant genes following direct DNA injection in vivo. However, $\beta$-Gal cannot be used to quantitate total levels of recombinant gene expression in DNA-injected hearts because the presence of even small amounts of blood in tissue homogenates interferes with the in vitro chromogenic $\beta$-Gal assay. In contrast to $\beta$-Gal, both $\mathrm{CAT}$ and luciferase can be used to accurately quantitate levels of reporter gene expression in total heart homogenates. CAT is a bacterial enzyme that catalyzes an acetylation reaction that is easily assayed by thinlayer chromatography (7). In the presence of an appropriate substrate and ATP, luciferase generates light which can be quantitated using a luminometer (8). Although both assays are convenient, luciferase assays have the advantage of being more sensitive than CAT assays. Thus, luciferase reporter constructs are a better choice if low levels of expression are expected. Whichever reporter plasmid is chosen, it is always necessary to include a reference plasmid in each DNA injection in order to correct for differences in transduction efficiencies in different animals. We generally include 25 $\mu \mathrm{g}$ of the pRSVCAT or pRSV-luciferase reference plasmids, respectively, in injections using luciferase and CAT reporter plasmids.

\section{Selection of Transcriptional Regulatory Sequences for Expressing Recombinant Genes in Cardiac Myocytes in vivo}

Several different viral and eukaryotic promoters have been used to program high-level gene expression in cardiac myocytes in vivo (2-5). These include the Rous sarcoma virus long terminal repeat (RSV LTR) $(9,10)$, the slow/cardiac troponin $\mathrm{C}$ promoter/enhancer (11), and the $\alpha$-myosin heavy chain promoter (12). This last promoter has the unique advantage of being thyroid hormone responsive both in vitro and in vivo $(3,12$, 13). Thus it could be used to modulate recombinant gene expression in vivo.

\section{Preparation of DNA for Cardiac Injections}

Closed circular plasmid DNA for direct intracardiac injection is prepared by standard alkaline lysis and $\mathrm{CsCl}$ gradient centrifugation (14). It is important to remove all ethidium bromide from the DNA by repeated extraction with water-saturated 1-butanol. Following butanol extraction, the DNA is dialyzed twice against 2-liter changes of $10 \mathrm{mM}$ Tris ( $\mathrm{pH}$ 7.8) for a total of $12 \mathrm{~h}$ at $4^{\circ} \mathrm{C}$ and ethanol precipitated. Thirty minutes prior to injection, the DNA is resuspended at a concentration of $1 \mathrm{mg} / \mathrm{ml}$ in sterile $10 \mathrm{mM} \mathrm{NaH}_{2} \mathrm{PO}_{4}$, $0.88 \%$ sodium chloride, $\mathrm{pH}$ 7.4. Because one report has shown that EDTA in the injection vehicle may be toxic to myocardial cells (4), EDTA is excluded from the DNA preparation and injection buffers. A total of $100-$ $125 \mu \mathrm{g}$ of DNA per animal is injected since studies in skeletal muscle have shown a linear dose response between 10 and $100 \mu \mathrm{g}$ of injected DNA (1).

\section{Surgical Procedure}

Both rats and mice can be used for intracardiac DNA injection. However, because of their larger size, rats are significantly easier to intubate and to inject with DNA. Most experiments have employed 6- to 11-weekold Sprague-Dawley rats, although animals as young as 4 weeks have been used successfully. Rats are anesthetized with $200 \mathrm{mg} / \mathrm{kg}$ of avertin (freshly prepared as a $5 \%(\mathrm{v} / \mathrm{v})$ solution in PBS) ip and ketamine (40 $\mathrm{mg} / \mathrm{kg}$ ) im. Mechanical ventilation of the animal is essential to prevent a fatal pneumothorax following entry of the pleural cavity. Therefore, immediately following anesthesia, animals are intubated using a 0 sized Miller short laryngoscope, modified for rat surgery by cutting the blade in half lengthwise, and a long 18 or 20-gauge angiocatheter, modified so that its length approximates the distance between the animal's mouth 
and the tracheal bifurcation. The endotracheal tube is secured with a suture. Rats are mechanically ventilated using a small-animal respirator set at a tidal volume of $1.5 \mathrm{ml}$ and a rate of 60 respirations $/ \mathrm{min}$. The anesthetized animal is positioned on its right side. The left side of the chest is shaved and sterilized using a betadine solution. A skin incision is made parallel to the ribs half-way between the shoulder and the costal margin. The superficial musculature is then dissected with fine scissors. This manipulation is usually accompanied by minor bleeding that can be stopped either by cautery or by pressure over the cut blood vessel. The fourth or fifth intercostal space is identified, and the intercostal muscles are cut with fine, blunt-tipped scissors. The actual incision should be made at midchest and just above the rib in order to avoid cutting intercostal vessels that course over the inferior margin of each rib. It is essential to enter the pleural cavity in a controlled manner. Sudden entrance of the chest, especially with sharp-tipped scissors, may puncture the underlying lung, invariably resulting in an inability to wean the animal from the ventilator at the end of the procedure. Once the chest wall has been opened, the intercostal incision is enlarged to allow the cross-action retractor to be inserted into the chest. This retractor should have blunt prongs to minimize the risk of inadvertent damage to the underlying lung. When the retractor has been opened, the lung is moved aside using cotton pledgets. The heart should be clearly visible (Fig. 1). The pericardium is dissected using fine forceps, and the cardiac apex is identified. This is the thickest portion of the heart and is therefore ideal for injection. One hundred microliters of DNA solution is then injected directly into the beating left ventricular apex using a tuberculin syringe and a 30 -gauge needle. There should be no air in the hub of the syringe, and the bevel of the needle should be facing upward. A successful injection is accompanied by blanching and blebbing of the entire apical and anterior walls of the heart. There may be a few premature ventricular contractions during the injection, but we have not observed sustained arrhythmias.

Following DNA injection the chest wall incision is closed in layers. The pleural cavity is closed using one or two interrupted nonresorbable sutures (silk or prolene) to appose the fourth and fifth ribs. Care must be taken not to puncture the lung with the suturing needle. Before the last suture is secured, a long 20-gauge angiocatheter attached to a syringe is inserted into the pleural cavity. As the last suture is tightened, air is withdrawn from the pleural cavity to reduce the pro- cedure-related pneumothorax. The muscle layer is then closed with interrupted resorbable suture. Finally, the skin is closed with staples. The animals are extubated after a brief trial of breathing off of the ventilator with the endotracheal tube in place and are allowed to recover under a warming lamp. They are then placed in individual cages to prevent postoperative animals from opening and infecting each other's surgical wounds.

\section{Tissue Harvest}

Cardiac myocytes express significant levels of recombinant genes as early as $48 \mathrm{~h}$ after direct DNA injections, and gene expression remains stable for at least 6 months $(2,3,5)$. Thus, the timing of tissue harvest depends entirely on the experiment being performed. In general, for studies of transcriptional regulation in the heart using CAT or luciferase reporter plasmid, hearts are harvested 5 days following DNA injection. To remove an injected heart, the animal is euthanized using pentobarbital $(100 \mathrm{mg} / \mathrm{kg}$, ip $)$. A midline sternotomy is performed using coarse dissecting scissors. The heart is quickly removed from the chest and rinsed extensively in ice-cold Dulbecco's PBS to remove any residual blood from the ventricle. As

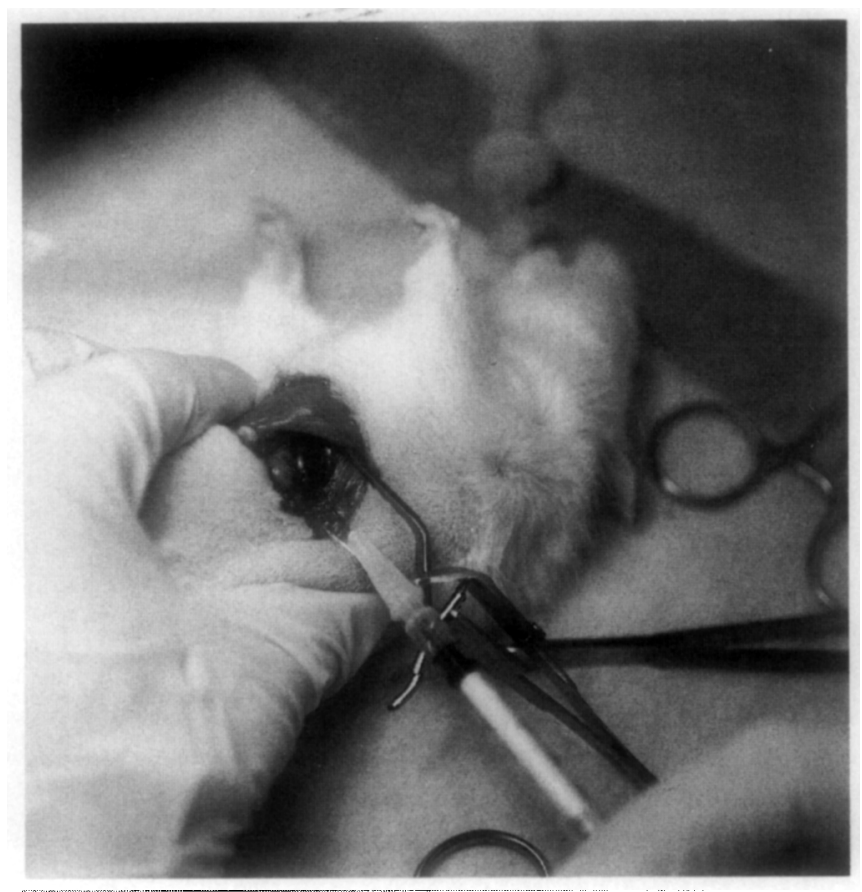

FIG. 1. View of the operative field during DNA injection into myocardium. DNA is injected into the apical portion of the left ventricle using a 30 -gauge needle and tuberculin syringe. 
described in detail below, hearts are prepared differently depending on the assay to be performed.

\section{$\beta$-Gal Assay}

As described above, the $\beta$-Gal assay can be used to histologically visualize myocardial cells that take up and express $\beta$-Gal expression vectors following direct DNA injection in vivo. The glutaraldehyde, ferro/ferricyanide, and X-Gal staining solutions (see Materials and Reagents) are prepared immediately prior to harvesting of the heart. Following harvest, the heart is cut into 3- to 5-mm-thick sections using a scalpel or razor blade and fixed in the glutaraldehyde solution for 10 min at room temperature. The heart sections are rinsed extensively in calcium-free PBS ( $\beta$-Gal is inhibited by calcium). The sections are then placed directly into the $\mathrm{X}$-Gal staining solution and incubated at $37^{\circ} \mathrm{C}$ in the dark overnight. The following morning, the heart slices are rinsed extensively in PBS, dehydrated with ethanol, and embedded in glycol methacrylate. The tissue is then sectioned at $4-\mu \mathrm{m}$ thickness using standard techniques. The sections are counterstained with hematoxylin and eosin to visualize the cardiac architecture.

\section{CAT Assay}

Chloramphenicol acetyltransferase catalyzes the acetylation of ${ }^{14} \mathrm{C}$-labeled chloramphenicol in the presence of acetyl-CoA. The radiolabeled chloramphenicol and its acetylated analogues can be separated using thin-layer chromatography and quantitated using either a betascope or liquid scintillography. The ratio of acetylated to unacetylated chloramphenicol is directly proportional to the level of CAT enzyme expressed in the heart.

Following harvest and washing, the atria are removed and discarded. The ventricles are then placed in $1 \mathrm{ml}$ of ice-cold homogenization solution $(0.25 \mathrm{M}$ Tris- $\mathrm{HCl}$, $\mathrm{pH} \mathrm{7.8)}$ if the tissue is to be assayed only for CAT activity or luciferase buffer 1 if both CAT and luciferase activities are to be measured. The tissue is homogenized on ice three times for $45 \mathrm{~s}$ each. The homogenate is allowed to cool on ice for $2 \mathrm{~min}$ between each homogenization step. The crude homogenate is centrifuged for $10 \mathrm{~min}$ in a Beckman J17 rotor at $6750 \mathrm{~g}$. Two microliters of the supernatant is assayed for protein content using a commercially available kit (Bio-Rad) and the remainder is stored at $-70^{\circ} \mathrm{C}$ until it is assayed for CAT activity. For CAT assays approximately $3 \mathrm{mg}$ of total protein is diluted into $100 \mu \mathrm{l}$ of either $0.25 \mathrm{M}$ Tris$\mathrm{HCl}, \mathrm{pH} 7.8$, or luciferase buffer 1 and heated to $68^{\circ} \mathrm{C}$ for $10 \mathrm{~min}$ to denature endogenous acetyltransferases. The sample is centrifuged at $14,000 \mathrm{rpm}$ in a microcentrifuge (Eppendorf) at room temperature and the pellet is discarded. The volume of the supernatant is readjusted to $100 \mu \mathrm{l}$ with the appropriate homogenization buffer.

For CAT assays the 100- $\mu$ l samples are mixed with $19 \mu \mathrm{l}$ of $2 \mathrm{M}$ Tris-HCl, $\mathrm{pH} 7.4,20 \mu \mathrm{l}$ of $4 \mathrm{mM}$ acetyl$\mathrm{CoA}$, and $8 \mu \mathrm{l}$ of $\left[{ }^{14} \mathrm{C}\right]$ chloramphenicol. The mixture is incubated for $2 \mathrm{~h}$ at $37^{\circ} \mathrm{C}$. The chloramphenicol and its acetylated analogues are then extracted with ethyl acetate and separated by thin-layer chromatography according to standard procedures (7). Radioactivity in the spots corresponding to unacetylated and acetylated chloramphenicol is quantitated either on a betascope or by liquid scintillography.

\section{Luciferase Assay}

Fresh luciferase buffers 1, 2, and 3 (see Materials and Reagents) and standard dilutions (1:10 ${ }^{4}, 1: 10^{5}$, $1: 10^{6}, 1: 10^{7}$, and $\left.1: 10^{8}\right)$ of the luciferase stock solution $\left(2 \mathrm{mg} / \mathrm{ml}\right.$ or $3 \times 10^{10} \mathrm{LU} / \mathrm{ml}$ in luciferase buffer 1 ) in luciferase buffer 1 are prepared immediately prior to the assay. All reagents are stored on ice until all the samples are ready to be tested. Immediately prior to the assay, $10 \mu \mathrm{l}$ of each luciferase standard solution plus $90 \mu 1$ of luciferase buffer 2 or $100 \mu \mathrm{l}$ of cardiac homogenate is added to $350 \mu \mathrm{l}$ of luciferase buffer 2 in a luminometer cuvette. The samples are then allowed to equilibrate to room temperature.

Samples are placed in the luminometer and assayed in series after the mechanical addition of $100 \mu \mathrm{l}$ of luciferase buffer 3 . Luciferase concentrations are read from a standard curve prepared by plotting the log luciferase concentration vs the log light units. For studies of transcriptional regulation using CAT reporter constructs and luciferase reference plasmids, CAT activities are corrected for differences in transduction efficiencies using the luciferase reference values from the same cardiac homogenates.

\section{RESULTS AND DISCUSSION}

\section{Patterns and Mechanisms of DNA Uptake and Expression Following Direct DNA Injection in Myocardium in vivo}

The efficiency, stability, and cell specificity of recombinant gene expression in the heart have been 
evaluated following the injection of several different $\beta$ Gal and CAT reporter plasmids. The results can be summarized as followed: (i) Recombinant genes are expressed in a small percentage $(<1 \%)$ of cardiac myocytes following direct DNA injection (Fig. 2) $(2,5)$. (ii) Expression is observed only in cardiac myocytes and is never detected in fibroblasts or vascular cells within the heart $(2,5)$. (iii) Recombinant gene expression is observed as early as $48 \mathrm{~h}$ after injection (2-5). Three reports have demonstrated stable expression of injected plasmids for periods of as long as 6 months $(2,3,5)$. In contrast, one study reported an immune-mediated extinction of recombinant gene expression within 28 days following injection (4). Whether this discrepancy reflects differences in injection technique, recipient animals, or DNA preparation remains unclear. (iv) A mild to moderate localized inflammatory response at the injection site has been noted within the first 5 days following injection (Fig. 2) (2,5). By 1 to 6 months this response resolved into an area of mild local fibrosis (2, $5)$. Changes in the preparation of DNA and the injec- tion solution may minimize this inflammatory response.

The mechanism of DNA uptake and expression by cardiac myocytcs following direct DN $\Lambda$ injection remains unclear. The ability to take up and express injected plasmid DNA is unique to muscle and may therefore reflect unique transport pathways or biophysical characteristics of the muscle cell lineage. An important question concerns the physical state of plasmid DNA following uptake into cardiac myocytes in vivo. Using Southern blot analysis, Acsadi et al. (4) have reported that the majority of the injected plasmid DNA is maintained in cardiac myocytes as linear or closed circular plasmid and does not appear to integrate into the genome or to undergo DNA replication. This finding is important because it suggests that the risk of mutagenesis from random integration of injected DNA is minimal. Current efforts are focused on increasing the efficiency of DNA uptake and expression in order to adapt the technique for the treatment of cardiovascular diseases.

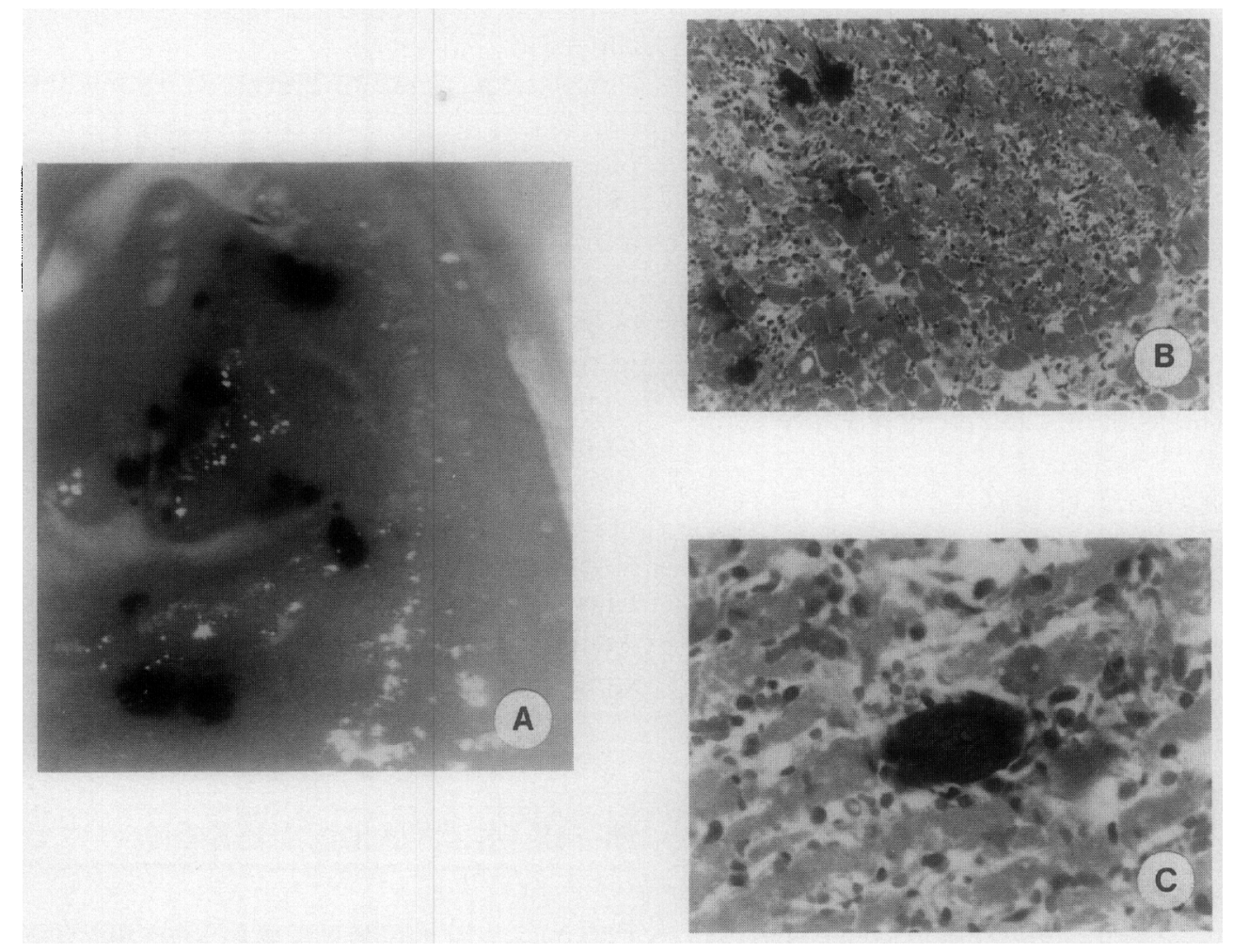

FIG. 2. Expression of recombinant $\beta$-Gal in cardiac myocytes following the direct injection of pRSV $\beta$-gal DNA into the left ventricular wall of Sprague-Dawley rats. Hearts were harvested, fixed in glutaraldehyde, and stained with X-Gal as described under Methods. (A) 18X view of a $3-\mathrm{mm}$ heart section. (B and C) $125 \times$ and $250 \times$ views, respectively, of $4-\mu \mathrm{m}$ sections from a heart 3 days after $\mathrm{pRSV} \beta$-gal injection. $\beta$-Gal activity is seen only within cardiac myocytes, which can be distinguished by their myofibrillar architecture. 
Mapping Transcriptional Regulatory Sequences Using Direct DNA Injection into Myocardium

We have used the direct injection of CAT reporter plasmids into myocardium to map the transcriptional regulatory sequences of the slow/cardiac troponin $\mathrm{C}$ (cTnC) gene in vivo (11). A series of deletion constructs containing sequences from the 5 flanking region of the murine $c$ TnC gene along with the $\mathrm{pRSV}$-luciferase reference plasmid were injected into the left ventricular walls of adult Sprague-Dawley rats. Five days later, the animals were sacrificed, and cardiac homogenates were assayed for CAT and luciferase activities. CAT activities were normalized for differences in transfection efficiencies by assaying the same cardiac homogenates for luciferase activities. Consistent with results obtained using in vitro transfections of neonatal rat cardiomyocytes, a reporter construct containing 156 $\mathrm{bp}$ of the cTnC gene $5^{\prime}$ flanking region (bp -124 to +32) reproducibly increased CAT transcription by more than 65 -fold following injection into the rat ventricle (Fig. 3). Further analysis of this element by direct injection of CAT reporter constructs demonstrated that it is composed of a minimal proximal promoter (bp -79 to +32 ) and a cardiac-specific transcriptional enhancer (bp -124 to -56 ) (11) (Fig. 3). These results were reproducibly obtained in multiple animals.

Direct DNA injection has also been used to examine the effects of hormonal manipulation on cardiac transcriptional regulation. Kitsis et al. (3) injected a lucif- erase reference gene coupled to the $\alpha$-myosin heavy chain promoter, a thyroid hormone-responsive, cardiac-specific regulatory element $(12,13)$, along with the pRSVCAT reference plasmid into the ventricular walls of euthyroid, hypothyroid, and hyperthyroid rats. Luciferase activities were normalized for differences in transfection efficiencies by assaying cardiac homogenates for CAT activity. Hypothyroid animals treated with triiodothyronine $\left(\mathrm{T}_{3}\right)$, a naturally occurring thyroid hormone, displayed significantly increased luciferase activity compared with untreated hypothyroid rats or euthyroid controls. The increase in activity was also seen in animals rendered hyperthyroid by injection of $\mathbf{T}_{3}$ compared to euthyroid control animals. Thus, genes introduced into cardiac myocytes by DNA injection can be hormonally modulated. Taken together, the results obtained in the $\mathrm{c} T \mathrm{TC}$ and $\alpha$-MHC systems demonstrate the usefulness of direct DNA injection for studies of cardiac-specific transcriptional regulation.

\section{Direct DNA Injection for Somatic Gene Therapy in the Heart}

The ability to stably express recombinant genes in the heart holds promise for the treatment of a variety of acquired and inherited cardiac diseases. These include inherited cardiomyopathies such as that associated with Duchenne muscular dystrophy and acquired cardiomyopathies such as that associated with chronic

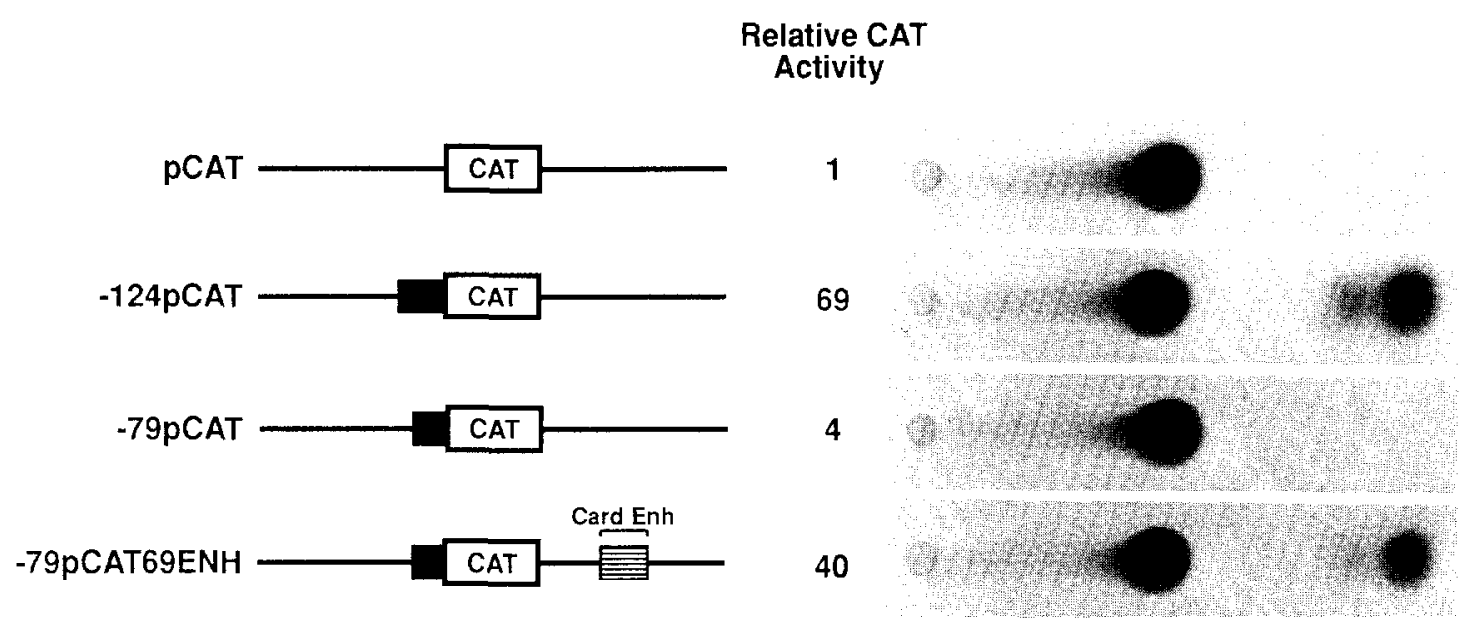

FIG. 3. In vivo analysis of the cis-acting sequences that regulate the expression of the cardiac troponin $\mathrm{C}$ (cTnC) gene. $100 \mu \mathrm{g}$ of $\mathrm{cThC}$ / CAT reporter constructs (shown schematically on the left), along with $25 \mu \mathrm{g}$ of the pRSV-luciferase reference plasmid, was injected directly into the left ventricular wall of Sprague-Dawley rats. Five days later, the animals were sacrificed and cardiac homogenates assayed for CAT and luciferase activities as described under Methods. A representative CAT assay is shown on the right. The data are presented as CAT activity following correction for differences in transduction efficiencies. 
ischemic heart disease. Effective gene replacement therapy for inherited cardiomyopathies will require significant improvements in the efficiency of recombinant gene uptake and expression. In contrast, it may be possible to stimulate collateral circulation in areas of ischemic myocardium by injecting expression vectors encoding secreted forms of mammalian angiogenesis factors into the myocardium. Toward this end we are currently injecting 4-week-old Sprague-Dawley rats with expression vectors encoding human fibroblast growth factor-5, a secreted and potent angiogenesis factor not normally expressed in myocardium.

\section{CONCLUSION}

We have described a method for in vivo transfer of recombinant genes into cardiac myocytes by direct injection of purified plasmid DNA into the beating left ventricular wall. This approach represents a novel and economical method for studying transcriptional regulation in cardiac myocytes in vivo. In addition, it holds promise as a potential method of somatic gene therapy in the heart.

\section{ACKNOWLEDGMENTS}

We thank A. K. Christensen, L. Dudus, and K. Brabac for assistance with embedding and staining of the muscle sections. We also thank B. Plunkett for help with the preparation of the manuscript.
E.B. is supported by the Neuromuscular Disease Research Fellowship of the Muscular Dystrophy Association. This work was supported in part by a grant from the Muscular Dystrophy Association to J.M.L.

\section{REFERENCES}

1. Wolff, J. A., Malone, R. W., Williams, P., Chong, W., Acsadi, G., Jani, A., and Felgner, P. L. (1990) Science 247, 1465-1468.

2. Lin, H., Parmacek, M. S., Morle, G., Bolling, S., and Leiden, J. M. (1990) Circulation 82, 2217-2221.

3. Kitsis, R., Buttrick, P., McNally, E., Kaplan, M., and Leinwand, L. A. (1991) Proc. Natl. Acad. Sci. USA 88, 1138-1142.

4. Acsadi, G., Jiao, S., Jani, A., Duke, D., Williams, P., Chong, W., and Wolff, J. A. (1991) New. Biol. 3, 71-81.

5. Leinwand, L. A., and Leiden, J. M. (1991) Trends Cardiovasc. Med. 1, 271-276.

6. Norton, P. A., and Coffin, J. M. (1985) Mol. Cell. Biol. 5, 281290.

7. Gorman, C. M., Moffat, L. F., and Howard, B. H. (1982) Mol. Cell. Biol. 77, 1432-1436.

8. de Wet, J. R., Wood, K. V., Deluca, M., Helinski, D. R., and Subramani, S. (1987) Mol. Cell. Biol. 7, 725-737.

9. Overbeek, P. A., Lai, S. P., Van Quill, K. R., and Westphal, H. (1986) Science 231, 1574-1577.

10. Swain, J. L., Stewart, T. A., and Leder, P. (1987) Cell 50, 719727.

11. Parmacek, M. S., Vora, A. J., Shen, T., Barr, E., Jung, F., and Leiden, J. M. (1992) Mol. Cell. Biol., in press.

12. Lompre, A-M., Nadal-Ginard, B., and Mahdavi, V. (1984) J. Biol. Chem. 259, 6437-6446.

13. Izumo, S., Nadal-Ginard, B., and Mahdavi, V. (1986) Science 231, 597-600.

14. Sambrook, J., Fritsch, E. F., and Maniatis, T. (1989) Molecular Cloning, a Laboratory Manual, 2nd ed., pp. 1.38-1.46, Cold Spring Harbor Laboratory, Cold Spring Harbor, NY. 